\section{On the presence of Long-billed Plovers Charadrius placidus in Rupa, Arunachal Pradesh in the summer months}

\section{Manari Greeshma}

C/o Lt. Colonel S. Sarkar, Military Hospital Hisar, Haryana 900383, India

Email: greeshma6@gmail.com

The Long-billed Plover is an East Asian bird, with a known distribution from Ussuri in southeastern Siberia, Russia, through North Korea and Japan to central China. Within the Indian subregion, it is known as a winter visitor to the eastern Himalaya and northeastern India, from northern Uttar Pradesh to the Assam Valley and Manipur; there are also a number of sight reports from Bangladesh and from Delhi to Sri Lanka and the Andamans (Rasmussen \& Anderton 2005). From India it is reported as a winter visitor (Grimmett et al. 1999; Grewal et al. 2002; Rasmussen $\&$ Anderton 2005).

According to Clements (2010), the species has three known breeding populations: the first in central China; the second in southeastern Siberia (Ussuri land and far eastern Russia), northeastern China and North Korea and the third on the Japanese islands of Honshu and Shikoku. Rasmussen \& Anderton (2005) state that it breeds from northeastern Asia to southwestern

Date of publication (online): 26 June 2011

Date of publication (print): 26 June 2011

ISSN 0974-7907 (online) | 0974-7893 (print)

Editor: Ramana Athreya

Manuscript details:

Ms \# 02742

Received 31 March 2011

Finally accepted 02 May 2011

Citation: Greeshma, M. (2011). On the presence of Long-billed Plovers Charadrius placidus in Rupa, Arunachal Pradesh in the summer months. Journal of Threatened Taxa 3(6): 1862-1863.

Copyright: (c) Manari Greeshma 2011. Creative Commons Attribution 3.0 Unported License. JoTT allows unrestricted use of this article in any medium for non-profit purposes, reproduction and distribution by providing adequate credit to the authors and the source of publication.

Acknowledgements: I am thankful to Mr. Rohan Kamath, Pune, Maharashtra for identifying the bird and pointing me in the right direction vis-à-vis their breeding areas and my husband Lt Colonel Satyasom Sarkar for his support.

OPEN ACCESS | FREE DOWNLOAD
China and possibly southeastern Tibet.

Materials and Methods:

Riverine shingle beds below the helipad in Rupa (27011'60'N \& 92024'E, 1800m), West Kameng District, Arunachal Pradesh, India, were visited frequently at dawn during 2009 and 2010. The frequency depended upon the highly unpredictable weather in that area, as well as other concerns. However, it is safe to say, that the area was visited at least once a week throughout the two years, except during long absences from the area in January 2010, April 2010, August-September 2010.

During the first year, birds were photographed opportunistically and identified. By the winter of 2009 , it emerged that the plovers observed through the summer months were Long-billed Plovers that were not known to spend the summer months in South Asia. Therefore, close observations were made through the summer of 2010, especially in June and July.

On every visit during 2010, one to three individuals of the Long-billed Plover were observed. They were rather wary and did not permit a close approach. Since they were always found in the same general area, it was assumed that they were residents there. It was not possible to ascertain whether these three individuals constituted a breeding unit or not since a proper search for their nesting sites was not made. Lacking suitable equipment for observing the birds without disturbing them, it was not possible to discover any nesting sites and rather than risk disturbing the birds and potentially driving them away by manually searching for their nests, it was thought better to leave them alone and confirm their breeding status at a later date when appropriate equipment is available. However, they were photographed (Images 1-3) to confirm their identity.

Through the months of May-July 2010 three separate individuals were observed inhabiting the shingle banks of the river and feeding in their typical solitary and unobtrusive fashion. Often they were seen singly but sometimes a pair was observed, foraging together and exhibiting other behaviour characteristic of pairs such as staying in close proximity to each other, reacting to threats or danger simultaneously, calling to each other. However, this behaviour could also have been unintentional. 


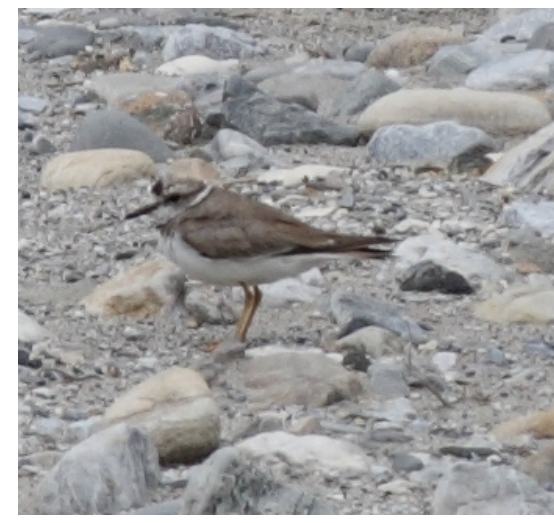

Image 1. Charadrius placidus - June 2010 (Rupa)

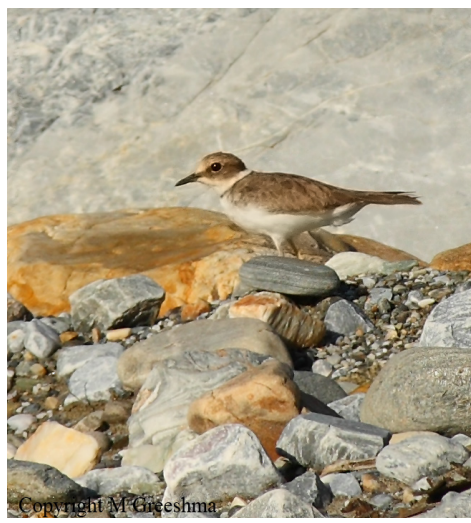

Image 2 . Charadrius placidus July 2010 (Rupa)

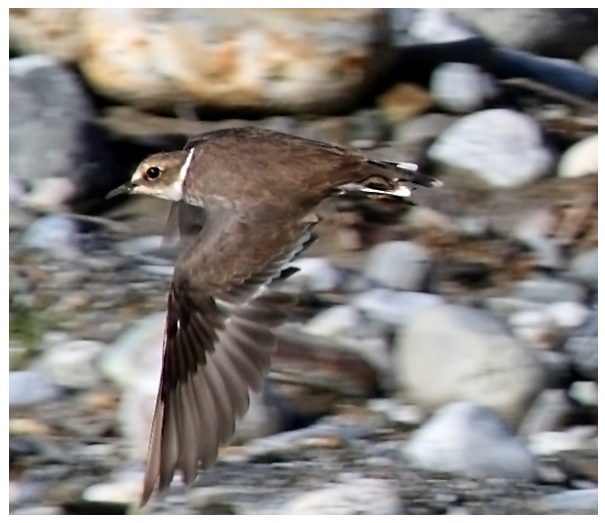

Image 3. Charadrius placidus - July 2010 (Rupa)
Discussion: Long-billed Plovers are known to breed on riverine gravel bars (Anonymous 2009; Katayama et al. 2009). The habitat they have been observed in during the present study perfectly matches the above descriptions of their breeding requirements and it is therefore not unlikely that the individuals observed in Rupa constitute a small breeding population of the species.

The individuals were present over a period of two consecutive years, strongly suggesting that they are residents rather than migrants. In any event, they were certainly not injured or otherwise incapacitated birds that were unable to complete the migration to their known summer breeding grounds in Eastern Asia, but a group of birds that prefers to reside in Rupa throughout the year rather than migrate to more favourable summering sites.

Conclusion: Individuals of the Long-billed Plover found on the riverine shingle beds below the town of Rupa, Arunachal Pradesh, India, appear to be year round residents in the area. It is not unlikely that they breed in Rupa in summer and would therefore constitute the only known breeding colony of this species in South Asia.

\section{REFERENCES}

Anonymous (2009). The rivers are alive! Birds Korea. www. birdskorea.or.kr. Accessed on 25.x.2010.

Clements, J.F. (2010). The Clements Checklist of Birds of the World. $6^{\text {th }}$ Edition - with updates to December 2010. Ithaca: Cornell University Press. < http://www.birds.cornell.edu/ clementschecklist/Clements\%206.5.xls/view>

Grewal, B., B. Harvey \& O. Pfister (2002). A Photographic Guide to The Birds of India. Periplus. Editions (HK) Ltd. Singapore, 512pp.

Grimmet, R., C. Inskipp \& T. Inskipp (1999). Pocket Guide to the Birds of the Indian Subcontinent. Oxford University Press, New Delhi, 84pp.

Katayama, N., T. Amano \& S. Ohori (2009). The effects of gravel bar construction on breeding Long-billed Plovers. Waterbirds 33(2): 162-168.

Rasmussen, P.C. \& J.C. Anderton (2005). Birds of South Asia. The Ripley Guide, Vol. 2. Smithsonian Institution and Lynx Edicions, Washington, D.C. \& Barcelona, 375pp. 